\title{
Impact of Media in Knowledge Gain about Cotton Cultivation
}

\author{
Reeta Devi Yadav*, Rita Goel and Beena Yadav \\ Department of Extension Education and Communication Management, CCS Haryana \\ Agricultural University, Hisar, India \\ *Corresponding author
}

\section{Keywords \\ Media, Knowledge, Impact, Cotton cultivation}

Article Info

Accepted: 06 June 2018 Available Online: 10 July 2018

\section{A B S T R A C T}

The study was conducted in purposively selected districts i.e. Fatehabad and Sirsa of Haryana, during 2014-15. Two blocks from each districts and one village from each selected blocks were selected and a proportionate sample of 60 male and 60 female respondents were selected randomly from the selected villages. The pre-exposure knowledge about recommended practices in cotton cultivation was assessed and respondents were exposed to the prepared and standardized media and the gain in knowledge after media exposure was tested. Results of the study revealed that most of the respondents belonged to lower middle age group, upper caste, female respondents were illiterate, male respondents were educated upto matric/higher secondary, farming occupation, belonged to joint family, had medium sized family, possessed pucca houses. Various aspects were covered in the prepared media (booklet and compact disc) such as cotton varieties, seed rate, seed treatment, depth of sowing, distance between row and plants, fertilizers and doses, nutrient deficiency, weedicides, pests and diseases management, protective cloths, soil health card, drip irrigation and tractor mounted fertilizer broadcaster. Significant gain in knowledge was observed in most of the aspects. High gain in knowledge was observed in cotton varieties, seed rate, seed treatment, depth of sowing, fertilizers and doses, cotton pests, tractor mounted fertilizer broadcaster, protective cloths for spray and soil health card.

\section{Introduction}

Media in the modern world are a force to reckon with. No task in the world today can be accomplished successfully and adequately without media support. The task of the media in development is twofold, to help remove illiteracy, fatalism, enlarge aspirations, increase and enhance social status, and secondly, to lend to overall national progress and prosperity, all other allied tasks are the byproducts of media inputs and media consumption. More the media inputs and greater the media consumption by the masses, will be the increased welfare of the nation and happiness and capacity building of farmers and farm women. Electronic media can play a vital role to inform farmers in the situation of urgency and emergency. Farmers can be informed quickly and swiftly about diseases 
and pest control, flood and changing weather. Farmers can also get the appropriate advices of experts through these media to cope with the emerging problems. In this way the farmers can get hold of their future planning in a better way. Important electronic media are pertinent to agriculture include radio, television, audio/video cassettes or CDs, telephone, mobile phone, internet and agriculture help line. However, these may also be used as an effective source of agricultural information. Farmers' awareness of these sources of agriculture information reflects its worth as an information sources. If a farmer is unaware of their availability, he/she will not be able to get benefit of this facility. $e$ Mausam web portal developed by NICHaryana state center, district unit Hisar in coordination with CCS Haryana Agricultural University, Hisar. The web portal is bilingual (English/Hindi) facilitating the farmers and scientist of farmer's community in weather forecast and agro advisories using Web and SMS based alerts through NIC SMS gateway, thereby providing more lead time to the farming community to minimize farm losses due to abnormal weather conditions. The world is now witnessing an information revolution. Information is power; interchange of information or thoughts brings about mutual cooperation and progress. The communication media including new information technologies play a vital role in bringing about planned national development.

\section{Materials and Methods}

The study was conducted in two districts namely Fatehabad and Sirsa purposively selected for the study in Haryana state. Two blocks from each district viz. Bhattukalan and Bhuna from Fatehabad and Nathusari Chopta and Sirsa from Sirsa and one village from each block i.e. Bhattu from Bhattukalan, Baizalpur from Bhuna block, Bakriyanwali from Nathusari Chopta and Panihar from Sirsa block were selected randomly. A proportionate sample of 60 male and 60 female respondents were selected randomly from the selected villages. For media standardization 30 experts in the field were selected as judges and prepared media were exposed to them and their scores were computed. Standardized printed booklet and compact disc (CD) were exposed to the male and female respondents. Pre-exposure and post-exposure knowledge of male and female respondents was assessed with the help of structured interview schedule. The collected data were quantified and interpreted by using suitable statistical tools such as mean score, reliability and paired ' $\mathrm{t}$ ' test.

\section{Results and Discussion}

Most of the respondents belonged to lower middle age group, upper caste, female respondents were illiterate, male respondents were educated upto matric/higher secondary, farming as main occupation, belonged to joint family, had medium sized family, possessed pucca house. Similar finding were reported by Gita (2010) which revealed that most of the respondents were illiterate, having medium family education status, joint family. Farming was their main occupation Deepti (2008) and Renu (2009) also support the findings. Majority of the respondents $(99.0 \%)$ possessed mobile phones, television (89.5\%), news papers $(33.5 \%)$, radio $(16.5 \%)$ and computer (13.0\%).

Developed and standardized media were exposed to the randomly selected male and female respondents and the pre-exposure and post -exposure mean scores and ' $t$ ' test were computed for all the messages on cotton cultivation practices in the selected districts viz., Fatehabad and Sirsa and presented in Table 1 of female respondents. It was evident from the Table 1 that female respondents succeeded in acquiring knowledge at the post- 
exposure level. Sufficient gain in knowledge was recorded in almost all the message viz., cotton varieties, seed rate, seed treatment, fertilizers, nutrient deficiency, weedicide, cotton pests and diseases, treatment of pests and diseases, protective measures, soil health card, drip irrigation and fertilizer broadcaster. Female respondents were already having knowledge regarding few sub-messages i.e. $B t$ cotton, distance between row, urea, whitefly and jassid.

Table.1 Gain in knowledge of female respondents regarding cotton cultivation

\begin{tabular}{|c|c|c|c|c|c|}
\hline Sr.No. & Activity & $\begin{array}{l}\text { Pre-Exp. } \\
\text { Mean } \\
\text { Score }\end{array}$ & $\begin{array}{l}\text { Post-Exp. } \\
\text { Mean } \\
\text { Score }\end{array}$ & $\begin{array}{l}\text { Gain in } \\
\text { knowledge }\end{array}$ & 't'value \\
\hline 1. & Cotton varieties & 13.15 & 22.66 & 9.51 & $25.98^{*}$ \\
\hline 2. & Seed rate & 1.00 & 1.91 & 0.91 & $25.47^{*}$ \\
\hline \multirow[t]{2}{*}{3.} & Seed treatment & 5.03 & 8.28 & 3.25 & $18.01 *$ \\
\hline & Doses & 5.00 & 5.81 & 0.81 & $5.46^{*}$ \\
\hline 4. & Depth of sowing & 1.00 & 1.70 & 0.70 & $11.73 *$ \\
\hline 5. & Distance between rows & 1.43 & 1.56 & 0.13 & 1.52 \\
\hline 6. & Distance between plants & 1.40 & 1.64 & 0.24 & $2.91^{*}$ \\
\hline \multirow[t]{2}{*}{7.} & Fertilizer & 5.75 & 7.75 & 2.0 & $17.54^{*}$ \\
\hline & Doses & 4.35 & 6.40 & 2.05 & $15.14^{*}$ \\
\hline 8. & Nutrient deficiency & 5.00 & 7.40 & 2.40 & $10.03^{*}$ \\
\hline \multirow[t]{2}{*}{9.} & Weedicide & 4.23 & 6.10 & 1.87 & $8.08^{*}$ \\
\hline & Doses & 4.00 & 5.56 & 1.56 & $6.54 *$ \\
\hline \multirow[t]{3}{*}{10.} & Cotton pests & 10.45 & 14.68 & 4.23 & $11.68^{*}$ \\
\hline & Pesticides & 9.00 & 12.35 & 3.35 & $6.59^{*}$ \\
\hline & Doses & 9.00 & 11.46 & 2.46 & $6.27 *$ \\
\hline \multirow[t]{3}{*}{11.} & Diseases & 7.00 & 10.03 & 3.03 & 7.06* \\
\hline & Treatment & 7.00 & 9.70 & 2.70 & $6.46^{*}$ \\
\hline & Doses & 7.00 & 9.31 & 2.31 & $6.19^{*}$ \\
\hline 12. & Protective cloths for spray & 1.15 & 2.0 & 0.85 & $18.28^{*}$ \\
\hline 13. & Capron & 1.10 & 2.0 & 0.90 & $23.04 *$ \\
\hline 14. & Cotton picking bag & 1.15 & 2.0 & 0.85 & $18.28^{*}$ \\
\hline 15. & Soil health card & 1.22 & 2.0 & 0.78 & $14.60^{*}$ \\
\hline 16. & Drip irrigation & 1.80 & 2.0 & 0.20 & $3.84^{*}$ \\
\hline 17. & $\begin{array}{l}\text { Tractor Mounted Fertilizer } \\
\text { Broadcaster }\end{array}$ & 1.10 & 2.0 & 0.90 & $23.04 *$ \\
\hline
\end{tabular}


Table.2 Gain in knowledge of male respondents regarding cotton cultivation

\begin{tabular}{|c|c|c|c|c|c|}
\hline Sr.No. & Activity & $\begin{array}{l}\text { Pre-Exp. } \\
\text { Mean } \\
\text { Score }\end{array}$ & $\begin{array}{l}\text { Post-Exp. } \\
\text { Mean } \\
\text { Score }\end{array}$ & $\begin{array}{l}\text { Gain in } \\
\text { knowledge }\end{array}$ & 't'value \\
\hline 1. & Cotton varieties & 14.11 & 23.31 & 9.20 & $22.24 *$ \\
\hline 2. & Seed rate & 1.91 & 2.00 & 0.09 & 2.31 \\
\hline \multirow[t]{2}{*}{3.} & Seed treatment & 6.53 & 9.16 & 2.63 & $13.85^{*}$ \\
\hline & Doses & 6.01 & 8.33 & 2.32 & $12.04 *$ \\
\hline 4. & Depth of sowing & 1.95 & 2.00 & 0.05 & 1.76 \\
\hline 5. & $\begin{array}{l}\text { Distance between } \\
\text { rows }\end{array}$ & 1.90 & 2.00 & 0.10 & 2.56 \\
\hline 6. & $\begin{array}{l}\text { Distance between } \\
\text { plants }\end{array}$ & 1.86 & 2.00 & 0.14 & $3.02 *$ \\
\hline \multirow[t]{2}{*}{7.} & Fertilizer & 7.93 & 8.00 & 0.07 & 2.05 \\
\hline & Doses & 7.15 & 8.00 & 0.85 & $6.06^{*}$ \\
\hline 8. & $\begin{array}{l}\text { Nutrient } \\
\text { deficiency }\end{array}$ & 5.68 & 9.85 & 4.17 & $27.65^{*}$ \\
\hline \multirow[t]{2}{*}{9.} & Weedicide & 6.21 & 7.55 & 1.33 & $12.65^{*}$ \\
\hline & Doses & 4.86 & 6.91 & 2.05 & $13.91^{*}$ \\
\hline \multirow[t]{3}{*}{10.} & Cotton pests & 16.00 & 17.83 & 1.83 & $10.38^{*}$ \\
\hline & Pesticides & 12.78 & 16.16 & 3.38 & $10.13^{*}$ \\
\hline & Doses & 10.81 & 15.18 & 4.37 & $10.29 *$ \\
\hline \multirow[t]{3}{*}{11.} & Diseases & 10.06 & 13.38 & 3.32 & $13.65^{*}$ \\
\hline & Treatment & 7.95 & 12.00 & 4.05 & $13.62 *$ \\
\hline & Doses & 7.41 & 10.78 & 3.37 & $8.76^{*}$ \\
\hline 12. & $\begin{array}{l}\text { Protective cloths } \\
\text { for spray }\end{array}$ & 1.26 & 2.0 & 0.74 & $12.74 *$ \\
\hline 13. & Capron & 1.15 & 2.0 & 0.85 & $18.28 *$ \\
\hline 14. & Cotton picking bag & 1.21 & 2.0 & 0.78 & $14.60^{*}$ \\
\hline 15. & Soil health card & 1.7 & 2.0 & 0.30 & $5.02 *$ \\
\hline 16. & Drip irrigation & 1.83 & 2.0 & 0.17 & $3.43^{*}$ \\
\hline 17. & $\begin{array}{l}\text { Tractor Mounted } \\
\text { Fertilizer } \\
\text { Broadcaster }\end{array}$ & 1.26 & 2.0 & 0.73 & $12.74 *$ \\
\hline
\end{tabular}

*Significant at $5 \%$ level of significance

The pre-exposure and post -exposure mean scores and ' $t$ ' test were computed for all the messages on improved cotton cultivation of male respondents and presented in Table 2 . The data clearly pointed to the fact that male respondents succeeded in acquiring knowledge at post-exposure level. Significant gain in knowledge was recorded in the messages related to improved, hybrid and desi varieties of cotton, nutrient deficiency identification in cotton, cotton pests and diseases identification and their management, weedicide, protective measures, soil health card, drip irrigation, power-drawn cultivator and fertilizer broadcaster. No change in knowledge was observed for few sub- 
messages i.e. Bt cotton, seed rate, depth of sowing, distance between row, fertilizers, gamexon, bowastin, whitefly, millybug and jassid, the reason for this was that the male respondents were already having knowledge regarding these messages. The overall knowledge showed sufficient increase in knowledge on cotton cultivation among the male respondents.

Significant gain in knowledge of male respondents was in cotton verities, seed treatment, weedicides and doses, nutrient deficiency, pest and disease management as reported by Singh and Roy (1993), Khurana et al., (2007), Rizwana and Paris (2009) and Sindu and Thakur (2011).

It is concluded that the significant gain in knowledge in cotton cultivation practices was assessed in almost all the messages was observed for female respondents, whereas significant gain in knowledge of male respondents was in cotton verities, seed treatment, weedicides and doses, nutrient deficiency, pest and disease management. Thus, it can be concluded that standardized media had positive impact on gain in knowledge among male and female respondents and may be developed on all aspects of agriculture, home science and animal sciences and may be exposed to the farmers. It may result in higher production and productivity.

\section{References}

Balasubramaniam, S. and Knight, J.A. 1997. Knowledge of farmers and high yielding varieties of paddy. Madras
Agriculture Journal, 64(3), pp. 385390

Deepti, 2008. Impact Assessment of All India Coordinated Research Project (AICRP) in Hume Science on Farm Women. M.Sc. Thesis, CCS, Haryana Agricultural University, Hisar.

Gita., 2010. Feasibility of Fruit Plant Nursery as an Enterprise for Rural Women. M.Sc. Thesis, CCS, Haryana Agricultural University, Hisar.

Khurana, D.G., Dhillon, D.S., Kumar, K. and Singh, M. 2007. Gain in Knowledge of Farmers due tv Multi Media Training Programmes. Indian J. Ext. Edu. 43: 76-80.

Renu, 2009. Capacity Building of Scheduled Caste Rural Women through Energy Conservation. Ph.D. Thesis, CCS Haryana Agricultural University, Hisar, Haryana

Rizwana and Paris, T.R. 2009. Knowledge level of paddy growers regarding improved practices uf paddy cultivation in Raipur, Chhattisgarh, India. International Journal of Rural Studies. 16 (1) 1-10

Sindu, K. and Thakur, N. 2011. Gender Variations in Knowledge Gain on Environmental Safeguarding using a Multi-media Package. Abstract in National Conference on Sustainable Development-A collective Vision. $31^{\text {st }}$ October and $1^{\text {st }}$ November 2011.

Singh, R.P. and Roy, N.K. 1993. Adoption behavior of tribal farmers with respect to high yielding varieties of rice, J. Res., Banaras Hindu University, 5 (1), pp. 17-22.

\section{How to cite this article:}

Reeta Devi Yadav, Rita Goel and Beena Yadav. 2018. Impact of Media in Knowledge Gain about Cotton Cultivation. Int.J.Curr.Microbiol.App.Sci. 7(07): 719-723. doi: https://doi.org/10.20546/ijcmas.2018.707.087 